Brit. J. vener. Dis. (1965), 41, 107.

\title{
AN ALLERGIC BASIS FOR NON-SPECIFIC URETHRITIS*
}

\author{
BY
}

\author{
T. E. T. WESTON
}

St. Thomas's Hospital, London

The incidence of non-gonococcal urethritis (NGU) or non-specific urethritis (NSU) has risen steadily during the past two decades. This has been shown both in the Ministry of Health returns from venereal disease clinics in England and Wales, and in epidemiological studies from abroad, notably those of Baier (1949) from the United States Forces in Japan, Babione and Graham (1952) from the United States Navy, Siboulet (1955) from Paris, and Gartman and Leibovitz (1955) from the United States Forces and indigent evacuees in Korea. It is also evident that, in spite of intensive study and extensive investigation, the condition remains essentially one of unknown aetiology.

The purpose of this paper is to consider the possibility of this disease having an allergic rather than an infective basis: that what we know as non-specific urethritis is a demonstration by a particular male urethra of sensitivity to something normally present in, and non-pathogenic to, the genital tract of a female consort, rather than the result of exposure to some as yet unidentified infective agent harboured by this consort.

Various other hypotheses have been put forward in the past, though most have either only been applicable to a small proportion of cases or have for some other reason failed to find favour. For instance, it is likely that a few cases are due to either chemical or physical trauma, while some seem likely to be due to trichomonal infection. Several workers, notably Sebastiani (1960), have stressed the psychosomatic elements of the condition. Studies of its relationship to a variety of organisms have been carried out and these will be discussed subsequently.

That uncomplicated NSU might be allergic in origin so far appears to have received little consideration, although several workers have entertained the

\footnotetext{
* Paper read to MSSVD on April 24, 1964.
}

possibility of the complications termed Reiter's disease being an auto-immune condition (Grimble, 1963). Steinberg (1938) considered that many cases of NSU were likely to be the result of food sensitivity, while Whitney (1931) thought that alcohol was likely to be responsible. More recently Nardelli $(1960,1961)$ has propounded the theory that the condition represents a response to the presence of endo-allergens formed by digestive and metabolic processes.

In this paper I have used the term non-specific urethritis (NSU) rather than non-gonococcal urethritis (NGU), since I wish to exclude from consideration all urethritis of known aetiology, such as the trichomonal and traumatic, and not merely the gonococcal.

The paper will have three parts. Part I is concerned with the theoretical consideration of the proposition that non-specific urethritis is an allergic-by which I include auto-allergic or auto-immune-rather than an infective condition. Part II is concerned with a retrospective study designed to explore this possibility. Part III is concerned with proposals for, and preliminary results from, a clinical and laboratory investigation of it.

\section{Theory of Allergic Basis for NSU}

There are two main groups of reasons for entertaining the hypothesis that NSU may have an allergic basis-those that directly favour an allergic aetiology and those which do so indirectly by seeming to exclude the likelihood of an infective aetiology.

In the first category are three clinical impressions, which I shall subsequently show to be valid, and which are of considerable significance. The first is that a much higher proportion of cases of NSU than of other sexually transmitted diseases occur in stable rather than casual relationships. This has previously been noted by Willcox (1954) who, in a comparison 
of over 600 male patients with NSU, and a similar number with gonorrhoea, found that NSU was more frequently contracted from regular consorts and occurred more often in men who were married, older, and of "white-collar" status. These findings were confirmed by Macfarlane and Johns (1958), who also noted the relative rarity of promiscuity amongst patients with NGU and their consorts. Boyd, Csonka, and Oates (1958), comparing the clinical and epidemiological histories of 200 male patients with NGU with a similar number with gonorrhoea, found that the NGU group contained a higher percentage of regular masturbators, that 75 per cent. of their infections followed extramarital intercourse, that the incubation period varied widely, and that alcohol, locally applied chemicals, and contraceptives were not factors in its aetiology.

The second impression is of a high rate of relapses or recurrences, often related to renewal of intercourse with the same consort, almost completely confined to those not using a condom, and the third is of a high incidence of consort-specificity, by which I mean that female A appears to be responsible for disease in male consort $B$ again and again, while male consort $\mathrm{C}$, who also enjoys her favours regularly, persistently escapes unscathed. Other factors favouring an allergic aetiology have also emerged from these studies, and will be discussed later.

Amongst factors favouring an allergic hypothesis by making the infective hypothesis unlikely, the chief is the failure, in spite of intensive and prolonged research citing various organisms, to demonstrate convincingly that any of them, apart from Trichomonas vaginalis and TRIC agent in some instances, plays a critical part in the causation of NSU. Rather, indeed, has this research, by its very volume and the negative nature of the results, tended to suggest that they do not.

To consider $T$. vaginalis first, this organism has been found increasingly frequently in male urogenital tracts of recent years, largely as a result of increased awareness of the possibility, more intensive searches for it, and improved techniques. The percentage of cases of NGU in which this organism has been demonstrated has varied from the 5.8 per cent. of Lanceley (1953) to the 41 per cent. of Feo, Varano, and Fetter (1956), most workers recording figures between 6 per cent. and 15 per cent. Weston and Nicol (1963) showed that particularly careful investigation of their patients had raised the percentage of positive cases from 3.6 in 1959 to 6.1 in 1962. It is generally agreed, however, that $T$. vaginalis is unlikely to be responsible for the great majority of cases of NGU,
The possibility of NGU being the result of mycotic infection has also received attention. Coutts (1948) reported two cases of urethritis in males in which Candida albicans appeared to be the cause. A review of the literature by Harkness (1950) suggested that mycotic urethritis usually occurred only after urethral trauma from syringeing or instrumentation. Auckland and Preston (1954) found fungus in the urogenital passages of 36 out of 722 men in a venereal disease clinic, 30 of those with fungus having evidence of NGU. Siboulet (1960) considered 5 to 10 per cent. of cases of NGU to be of fungal origin.

Culture of urethral discharge or urethral scrapings from patients with NGU has either resulted in no growth or in colonies of organisms frequently found in the anterior urethra as commensals. Many workers, amongst them Ambrose and Taylor (1953), Willcox (1955a), Hirakida (1958), and Röckl and Nasemann (1959) have shown that these organisms are essentially secondary invaders and usually play no part in the primary condition. Morrison (1963) was unable to demonstrate a causative organism by anaerobic culture.

A haemophilus-type organism was cultured by Leopold (1953) from the urine of 53 of 965 (5.5 per cent.) of a sample of men of unspecified condition, 2 of 18 (11 per cent.) men with a history of NGU, from the cervical secretion of 27 per cent. of a sample of women, and from the urine of 4 out of 9 of their husbands. A similar organism was described by Gardner and Dukes $(1954,1955)$ and named Haemophilus vaginalis. It was felt that this organism might be a factor in the aetiology of NGU, and work by Gardner and Dukes (1959), Edmunds (1959), and Heltai (1959) tended to confirm this. The work of others, however, such as Amies and Jones (1957), Lapage (1961), and Zinnemann and Turner (1963) has cast considerable doubt both on the identity of the organism and its relationship to NGU. Controlled studies demonstrating a relationship between the presence of this organism and NGU have not been recorded.

The possibility that pleuropneumonia-like organisms (PPLO) might be causally related to NGU has also received attention. Since Dienes and Smith (1942) found PPLO in male urethral and prostatic secretions many workers have investigated the frequency of occurrence of this organism both in patients with NGU and in asymptomatic consorts. Findings have varied widely with an incidence of from 7 per cent. (Salaman, 1946; Durel, RoironRatner, Siboulet, and Sorel, 1954) to 84 per cent. (Ford and Duvernet, 1963) in men with NGU, and from nil (Beveridge, Campbell, and Lind, 1946; 
Harkness and Henderson-Begg, 1948; Wagner, Morse, and Kuhns, 1953) to over 50 per cent. (Shepard, 1954; Freundt, 1956) in asymptomatic males. Kleineberger-Nobel (1959) and Wilkinson and Whittington (1959) were unable to demonstrate the organism in a series of boys under 13 years of age, but Röckl, Nasemann, and Stettwieser (1954) found it in 4 out of 31 children. Less work has been done in relation to females, but Beveridge and others (1946) and Harkness (1950) isolated PPLO from the female consorts of from 25 per cent. to 40 per cent. of a small series of pairs, while Nicol and Edward (1953) found that positive cultures were obtained more often from the consorts of men who themselves had PPLO than from those who did not, although they were unable to demonstrate any difference in the clinical pattern of NGU in patients with positive PPLO cultures as compared with those without. The serology of various samples of patients and controls has been tested for antibodies by Card (1959) and Wilkinson and Whittington (1959), but no correlation with clinical disease or with the results of PPLO cultures was established. The significance of the presence or absence of PPLO in patients with NGU remains uncertain. A similar situation obtains with regard to the special "T-strain" of PPLO described by Shepard (1956).

The possibility that NGU may have a viral aetiology has also recently attracted increased attention. The original claim to have found inclusion bodies in the urethral epithelial cells of patients with NGU was made by Lindner (1910), Siebert (1910), and Halberstaedter and von Prowazek (1910) more than half a century ago. Similar findings were subsequently recorded by Thygeson and Mengert (1936), Thygeson and Stone (1942), Harkness (1945), Johnston and McEwin (1945), and Williams (1946). Further studies by various workers gave an incidence of inclusion bodies in material from cases of NGU ranging from nil (Bedson, 1950) to 17 per cent. (Moustardier, Brisou, and Perrey, 1954), most workers getting results of 3 per cent. to 4 per cent. Attempts by Willcox, Howard, and Findlay (1954), Ford (1956, 1958), Csonka and Furness (1960), and Whittington (1962) to isolate a virus by inoculating urethral scrapings from cases of NGU on to a wide variety of media all failed, though Siboulet and Galistin (1962) claimed success with yolk-sac cultures.

Considerable interest has recently been shown in the possibility of there being a relationship between NSU and the agent responsible for the various manifestations of trachoma inclusion conjunctivitis (TRIC agent). The possibility that this relationship might exist was first stimulated by the demonstration by Halberstaedter and von Prowazek (1910) of inclusion bodies in cervical scrapings of the mothers of infants with inclusion blennorrhoea following the demonstration three years earlier of similar inclusion bodies in the conjunctival epithelial cells of such infants. In the same year Lindner (1910) demonstrated inclusion bodies in the urethra of cases of NGU.

Further studies of the possibility of a connexion between inclusion conjunctivitis and genital infection have recently been carried out (Jones, 1964; Jones, Al-Hussaini, and Dunlop, 1964; Al-Hussaini, Jones, and Dunlop, 1964; Dunlop, Jones, and Al-Hussaini, 1964), who, on investigating the parents of 5 babies suffering from TRIC virus conjunctivitis found the virus in the cervix of one mother and the urethra of one father. The relationship of TRIC virus to NSU awaits clarification; the evidence so far is that it can be demonstrated in some cases, but to attribute causal rather than casual significance to its presence is not yet justifiable.

It is also of interest that Pearson, Waksman, and Sharp (1961) have, by the injection of Freund's adjuvant into rats, produced experimentally a condition closely resembling clinical Reiter's disease and NGU in humans.

The infective hypothesis also has to meet the objection that it has not proved possible to relate either the bacteriology or the clinical features of the male with NSU with what is found in his female consort. In many consorts there is no evidence of disease of any sort, the findings being of a normal cervix and vagina with mucoid secretion only. In others there may be a low-grade cervicitis characterized by the presence of mucopus in the cervix, possibly accompanied by slight cervicitis or cervical erosion, an appearance which is common in multiparae and accepted as being of little if any pathological significance. In the absence of specific infection with gonococci, trichomonas, or monilia, it is rare to see clinical appearances in any way either abnormal in themselves or comparable with those in the male.

Further doubt is thrown on the likelihood of a bacterial basis for NSU by the relatively slight effect that chemotherapy appears to have on its course and outcome. Various workers have investigated the results of withholding treatment in NSU, and others have investigated the effects of withholding treatment as compared with the administration of a wide variety of antibiotics. Thus, amongst those who had no treatment, Gartman and Leibovitz (1955) found that $58 \cdot 5$ per cent. recovered spontaneously, Laidig and Berg (1957) 84 per cent., Fowler (1958) 79 per cent., and Leach (1959) 61 per cent, 
Results with antibiotics have varied considerably. With sulphonamides success rates of from 22 per cent. (Doyle, Gill, and Laird, 1957) to $62 \cdot 5$ per cent. (Willcox, 1953) were reported. Morton and Morrison (1963) reported 70 per cent. cures with ampicillin; with streptomycin alone results of up to 70 per cent. cure (Morton and Read, 1957); for streptomycin and sulphonamides from 69 per cent. (Lyall, 1953) to 81.5 per cent. (Kershaw and Lindsay, 1956); for the tetracyclines from 63 per cent. (Harkness, 1953) to 100 per cent. (Crouch, Reese, and Boudreau, 1953); for erythromycin from 54 per cent. (Haight, 1956) to $77 \cdot 2$ per cent. (Willcox, 1955b); for spiramycin 8 per cent. (Willcox, 1958); for oleandomycin 73 per cent. (Willcox, 1959); for sigmamycin 71 per cent. (Leach, 1959). Morton and Read (1957), comparing results in patients given a variety of treatments, obtained cure rates of 48 per cent. with potassium citrate mixture, 55 per cent. with Sulphatriad, 70 per cent. with streptomycin, 73 per cent. with chloramphenicol, 76 per cent. with Aureomycin, and 85 per cent. with Terramycin. It is thus clear that, with the possible exception of the tetracyclines, antibiotics do not have a marked effect on the resolution rate of NSU. It was generally noticed, however, that they accelerated the process. This may well have been due to their effect in limiting secondary infection rather than to their influencing the primary process.

There are also clinical features of NSU which appear to militate against the allergic hypothesis. The first of these is that patients with NSU appear not to have that predisposition to allergic conditions that one would expect, were this an allergic disease. It is recognized that some people are more liable to allergic conditions, such as asthma, contact dermatitis, hay-fever, and so on, than others. They have been labelled atopic subjects. Careful history-taking, however, has failed to reveal an undue proportion of such atopic subjects amongst patients suffering from NSU. Allergic conditions are not confined to such people and some categories of recognized allergic response-for instance, drug sensitivity and other forms of Type 1 (anaphylactic) response-also show no evidence of being related to constitutional allergic predisposition; so that this factor does not constitute an absolute bar to the allergic hypothesis.

The second difficulty is the suggested failure of NSU to respond to the administration of corticosteroids. This was reported by Ambrose and Taylor (1953), but on only three patients, by Grimble and Csonka (1955), and Willcox (1959). Grimble and Csonka's work was concerned with the local application of hydrocortisone ointment and resulted in symptomatic improvement which was not maintained when treatment was discontinued. Willcox's series involved the use of terramycin and prednisolone together, it being shown that the addition of prednisolone did not materially affect the number of cures. Similar results were reported by Longhin, Teodosiu, and Vintici (1959). Schulte, Reynolds, and Hammer (1954) noted good results from the topical application of cortisone acetate in patients who had failed to respond to other kinds of treatment.

The effect of antihistamines on NSU does not appear to have been investigated. Forgan (1964) and Levy (1964), however, reported good results from its use in cases of Reiter's disease which was resistant to other forms of treatment.

\section{Possibility of Allergic Basis for NSU}

The possibility of an allergic basis for NSU having been conceived, the next step seemed to be to test it against past clinical experience. Accordingly, the records of patients presenting at St Thomas's Hospital with NSU in 1959 were searched. Those who themselves either had trichomoniasis or were consorts of female patients in whom it was found, those who defaulted before completion of surveillance, and those who resided outside London (since they would have biased the series in that they were likely to attend elsewhere in the event of a recurrence) were discarded, and the first hundred other cases of NSU accepted for submission to analysis. No incident was regarded as a recurrence unless it occurred more than three months after previous therapy.

The questions posed were as follows. Was there a history of previous NSU, and if so, had it been contracted from the same consort as the current episode or not? What was the length of sexual acquaintanceship with the relevant consort or consorts? In those cases in which recurrence subsequently occurred, did it return without further intercourse, following intercourse with the same consort, or following intercourse with a different consort? If with the same consort, was it after she had herself been investigated and treated, or not? It will be seen that any errors introduced into this study by incomplete histories will tend to decrease rather than increase the figures favourable to an allergic hypothesis. The results of this study were tabulated and several important facts about the natural history of NSU emerged. It must be borne in mind that these figures represent no more than a conservative estimate since they can take no account of those patients who, although locally resident, had recurrences and attended elsewhere.

Table I shows that 70 per cent. of patients with NSU have a history of previous or subsequent NSU, 
TABLE I

INCIDENCE OF PATIENTS WITH HISTORY OF PREVIOUS OR SUBSEQUENT NSU

\begin{tabular}{|c|c|c|c|c|c|c|}
\hline \multicolumn{5}{|c|}{ NSU } & No. & Per cent. \\
\hline $\begin{array}{l}\text { Positive } \\
\text { Negative } \\
\text { Uncertain }\end{array}$ & $\begin{array}{l}\ldots \\
\ldots\end{array}$ & $\begin{array}{l}\ldots \\
\ldots \\
\ldots\end{array}$ & $\begin{array}{l}\ldots \\
\ldots \\
\ldots\end{array}$ & $\begin{array}{l}\ldots \\
\ldots \\
\ldots\end{array}$ & $\begin{array}{r}70 \\
29 \\
1\end{array}$ & $\begin{array}{r}70 \\
29 \\
1\end{array}$ \\
\hline
\end{tabular}

TABLE II

FREQUENCY OF RECURRENCE OF DISEASE IN PATIENTS WITH NSU

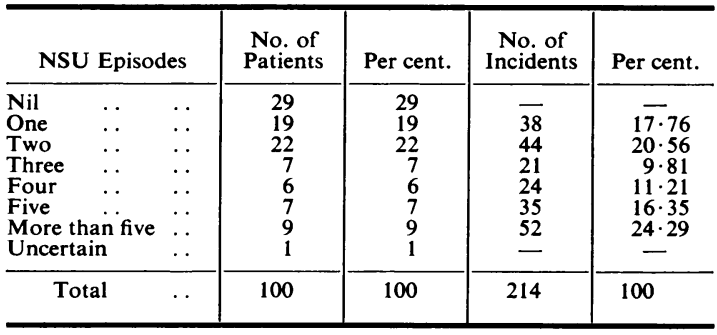

Table II indicates that over two-thirds of these patients have more than one other episode of NSU and over one-quarter have more than four other such episodes.

Table III analyses the circumstances in which nearly one-quarter had recurrence without further intercourse, that nearly two-thirds had recurrence associated with repeated intercourse with the same consort, and that there was little difference in the incidence of recurrence between couples in whom the female partner had also been treated and those in which she had not. With regard to the total number of incidents related to the group as a whole, under 20 per cent. involved those who had had intercourse with a new consort and over 70 per cent. those who had renewed intercourse with their former consorts.

Table IV seeks to analyse further the sexual histories of those with recurrences. While recurrence occurred in less than 10 per cent. of cases spontaneously or following intercourse with a new consort, in over 50 per cent. it occurred where there was recurrences occurred. It is of particular interest that

TABLE III

ANALYSIS OF CIRCUMSTANCES OF RECURRENCE OF NSU

\begin{tabular}{|c|c|c|c|c|c|}
\hline \multicolumn{2}{|c|}{ Relapse occurred } & \multirow{2}{*}{$\frac{\begin{array}{c}\text { No. of } \\
\text { Patients }\end{array}}{29}$} & \multirow{2}{*}{$\begin{array}{c}\text { Per cent. } \\
20 \cdot 13\end{array}$} & \multirow{2}{*}{$\begin{array}{c}\begin{array}{c}\text { No. } \\
\text { of Inci- } \\
\text { dents }\end{array} \\
\end{array}$} & \multirow{2}{*}{ Per cent. } \\
\hline Not at all & . & & & & \\
\hline Spontaneously & . & 27 & $18 \cdot 75$ & 40 & $18 \cdot 43$ \\
\hline $\begin{array}{l}\text { Following expo } \\
\text { same consort }\end{array}$ & $\begin{array}{l}\text { sure with } \\
\text { treated.. }\end{array}$ & 33 & $22 \cdot 91$ & 74 & $34 \cdot 10$ \\
\hline $\begin{array}{l}\text { Following expo } \\
\text { same consort }\end{array}$ & $\begin{array}{l}\text { sure with } \\
\text { untreated }\end{array}$ & 37 & $25 \cdot 60$ & 80 & $36 \cdot 86$ \\
\hline $\begin{array}{l}\text { Following expo } \\
\text { different cons }\end{array}$ & $\begin{array}{l}\text { sure with } \\
\text { ort } \quad .\end{array}$ & 15 & $10 \cdot 41$ & 20 & $9 \cdot 22$ \\
\hline Uncertain & . & 3 & $2 \cdot 08$ & 3 & $1 \cdot 38$ \\
\hline Totals & . & 144 & 100 & 217 & 100 \\
\hline
\end{tabular}

TABLE IV

ANALYSIS OF SEXUAL HISTORIES ASSOCIATED WITH RECURRENCE OF NSU

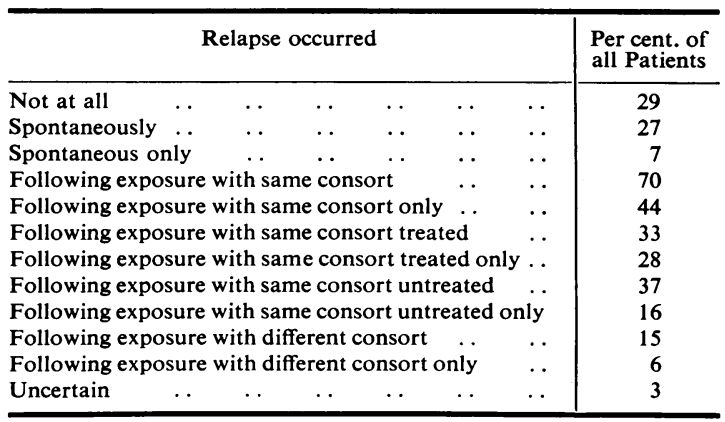

no question of intercourse other than with the same consort. In the remaining cases the history revealed several other possible factors associated with recurrence. Tables V and VI elaborate and confirm these conclusions.

Table VII shows that although a substantial percentage of patients with NSU had been having intercourse for more than a year, in relatively few does it occur, as one would expect with an infective condition, following a single or initial exposure; the largest number of cases occurs within less than three months of regular intercourse, usually after not more than six exposures, and half the cases are

TABLE V

NO. OF PATIENTS EXPERIENCING VARIOUS TYPES OF RECURRENCE OF NSU

\begin{tabular}{|c|c|c|c|c|c|c|c|c|c|c|}
\hline \multirow[b]{2}{*}{ Relapse Occurred } & & \multicolumn{9}{|c|}{ No. of Recurrences } \\
\hline & & Nil & One & Two & Three & Four & Five & $\begin{array}{l}\text { More } \\
\text { than } \\
\text { Five }\end{array}$ & $\underset{\text { certain }}{\text { Un- }}$ & Total \\
\hline $\begin{array}{l}\text { Spontaneously . . } \\
\text { Following exposure with same consort treated } \\
\text { Following exposure with same consort untreated } \\
\text { Following exposure with different consort } \ldots\end{array}$ & $\begin{array}{l}\cdots \\
\cdots \\
\cdots\end{array}$ & $\begin{array}{l}71 \\
63 \\
61 \\
81\end{array}$ & $\begin{array}{l}15 \\
15 \\
18 \\
10\end{array}$ & $\begin{array}{r}8 \\
11 \\
9 \\
6\end{array}$ & $\begin{array}{r}3 \\
4 \\
2 \\
\end{array}$ & $\begin{array}{r}\mathbf{2} \\
\mathbf{3} \\
\end{array}$ & $\overline{-}$ & $\begin{array}{r}\overline{2} \\
2 \\
\end{array}$ & $\begin{array}{l}\mathbf{3} \\
\mathbf{3} \\
\mathbf{3} \\
\mathbf{3}\end{array}$ & $\begin{array}{l}100 \\
100 \\
100 \\
100\end{array}$ \\
\hline
\end{tabular}


TABLE VI

ANALYSIS OF INCIDENTS OF RECURRENCE OF NSU IN VARIOUS CIRCUMSTANCES

\begin{tabular}{|c|c|c|c|c|c|c|c|c|c|c|}
\hline \multirow[b]{2}{*}{ Relapse Occurred } & & & \multicolumn{8}{|c|}{ No. of Recurrences } \\
\hline & & & Nil & One & Two & Three & Four & Five & $\begin{array}{l}\text { More } \\
\text { than } \\
\text { Five }\end{array}$ & Total \\
\hline $\begin{array}{l}\text { Spontaneously } \ldots \text { with same consort treated } \\
\text { Following exposure with } \\
\text { Following exposure with same consort untreated } \\
\text { Following exposure with different consort } \quad \text {.. }\end{array}$ & $\begin{array}{l}\cdots \\
\cdots \\
\cdots\end{array}$ & $\begin{array}{l}\cdots \\
\cdots \\
\cdots\end{array}$ & $\bar{Z}$ & $\begin{array}{l}15 \\
15 \\
18 \\
10\end{array}$ & $\begin{array}{l}16 \\
20 \\
16 \\
12\end{array}$ & $\begin{array}{r}9 \\
12 \\
6 \\
-\end{array}$ & $\begin{array}{r}-8 \\
12 \\
-\end{array}$ & $\overline{10}$ & $\begin{array}{l}\overline{16} \\
19 \\
-\end{array}$ & $\begin{array}{l}40 \\
71 \\
81 \\
22\end{array}$ \\
\hline
\end{tabular}

TABLE VII

ANALYSIS OF LENGTH OF SEXUAL ACQUAINTANCESHIP WITH CONSORT OF PATIENTS WITH NSU

\begin{tabular}{|c|c|c|c|c|}
\hline NSU & & & No. of & Per cent. \\
\hline $\begin{array}{l}\text { Single exposure only } \\
\text { Regular (less than } 3 \text { months) } \\
\text { Regular ( } 3 \text { to } 6 \text { months) } \\
\begin{array}{l}\text { Regular (6 months to } 1 \text { year) } \\
\text { Regular (more than } 1 \text { year) } \ldots\end{array}\end{array}$ & $\begin{array}{l}\ldots \\
\cdots \\
\cdots\end{array}$ & $\begin{array}{l}\cdots \\
\cdots \\
\cdots \\
\cdots\end{array}$ & $\begin{array}{r}8 \\
28 \\
12 \\
7 \\
25\end{array}$ & $\begin{array}{l}10 \\
35 \\
15 \\
8 \cdot 75 \\
31 \cdot 25\end{array}$ \\
\hline
\end{tabular}

patients who have been having intercourse with the same consort for less than six months.

Tables VIII and IX analyse the distribution of incidents of NSU amongst patients with various types of sexual history.

The particular points that this study establishes are the frequency of recurrence, especially following exposure with the same consort, irrespective of whether or not she had been treated, and the tendency for the first attack, of what must now be regarded as an essentially recurrent condition, to

TABLE VIII

ANALYSIS OF TYPES OF CONSORTS OF PATIENTS WITH RECURRENT NSU

\begin{tabular}{c|r|r|r|r|r|r|r}
\hline NSU & Nil & One & Two & Three & Four & Five & $\begin{array}{c}\text { More } \\
\text { than } \\
\text { Five }\end{array}$ \\
\hline $\begin{array}{c}\text { Casual consorts } \\
\text { Regular consort } \\
\text { treated . }\end{array}$ & 13 & 8 & 5 & - & - & - & - \\
$\begin{array}{c}\text { Regular consort } \\
\text { untreated .. }\end{array}$ & 16 & 12 & 7 & 1 & 2 & 4 & 2 \\
\hline
\end{tabular}

TABLE IX

RELATIONSHIP OF INCIDENCE OF RECURRENCE OF NSU TO VARIOUS TYPES OF CONSORT

\begin{tabular}{c|c|c|c|c|c|c|c|c}
\hline NSU & Nil & One & Two & Three & Four & Five & $\begin{array}{c}\text { More } \\
\text { than } \\
\text { Five }\end{array}$ & Total \\
\hline $\begin{array}{c}\text { Casual } \\
\text { consorts }\end{array}$ & - & 8 & 10 & - & - & - & - & 18 \\
$\begin{array}{c}\text { Regular } \\
\text { consort } \\
\text { treated } \\
\text { Regular } \\
\text { consort } \\
\text { untreated }\end{array}$ & - & 5 & 22 & 15 & 12 & 10 & 16 & 80 \\
\hline
\end{tabular}

occur after more than one exposure but within the first three months of the relationship. This last phenomenon is highly suggestive of reinforcement of antibody formation in the male by periodic provocation with the female antigen, whatever it may be, leading to hypersensitivity. This is the typical mode of development of an allergic condition. Indeed, all the factors elucidated by this study suggest the presence of an allergic rather than an infective reaction.

\section{Clinical and Laboratory Studies}

Supposition and retrospective studies are, of course, not enough, and clinical and laboratory evidence must also be collected and discussed. The basic difficulty is that of establishing distinguishing criteria between allergic and infective phenomena in general and applying them to the clinical situation which we know as NSU. This difficulty is more substantial than might at first sight be imagined, for although extreme examples of both infective and allergic conditions (such as, for instance, bronchitis and asthma) are distinguishable both at the bedside and in the laboratory, this distinction is based on clear differences between them as particular clinical conditions as much as between them as representatives of infective and allergic disease processes respectively.

For these processes and their behaviour are in many ways similar, since both are mediated through the antigen-antibody, hypersensitivity, immunity chain of reaction. Thus the demonstration of an antigenic relationship between the couple concerned, difficult though it may be, really takes us little further forward-for it could just as well be based on an infective as on an allergic situation. Indeed, it appears that there are no absolute criteria or tests that will allow one to proclaim with certainty that NSU is an allergic rather than an infective disease or vice versa.

There are pointers, however, and it is these that must now be identified and pursued so that the balance of probability between the two possibilities may be established. 
In doing so I have found it helpful to regard the phenomenon of NSU in the light of the basic principles of bacteriology and immunology and, as well, to seek illumination from possible parallels between infective and allergic conditions both occurring in the same system elsewhere in the body. It has thus been helpful to consider what similarities may exist, for instance, between the bronchitis-asthma antithesis or the infective rhinitis-allergic rhinitis antithesis, and the gonorrhoea-NSU antithesis.

I have already remarked that although it is usually not difficult to demonstrate the existence of an infective situation, there is no single test which will establish beyond doubt that a certain disease, or even a certain immunological reaction, is allergic rather than infective. Rather, is it a case of weighing all the

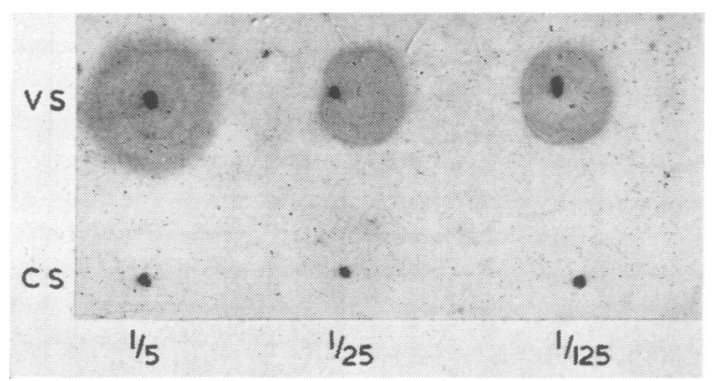

FIG. 1.-Results of placing drops of female consort's vaginal and cervical secretions in dilutions of $1: 5,1: 25$, and $1: 125$, on cellulose acetate paper impregnated with patient's urethral cellulose
discharge.

discernible factors and establishing, first, a possibility and ultimately a probability in favour either of infection or allergy. To do this every shred of clinical evidence and every one of the now multitudinous laboratory devices which are available must be considered.

First, what lead does the clinical pattern of the disease and the results of previous studies give? They depict a condition characterized by frequency of recurrence, especially following exposure to the same consort, irrespective of whether she has been treated or not, and the tendency for the first attack to occur early in sexual acquaintanceship, but not following initial or solitary risk. This is a typical allergic picture.

Following a consideration of the clinical pattern of the disease the next most obvious study is that of the various exudates concerned. In this connexion there is in hand a comparative study of the cellular characteristics of the urethral discharge of patients with primary NSU, gonococcal urethritis, postgonococcal NSU, trichomonal urethritis, and of urethral scrapings from asymptomatic males having regular sexual intercourse, and male virgins, as well as of the urethral, vaginal, and cervical secretions of the consorts of patients and of non-related females. It is too soon to pronounce on this study.

The immunological reactions of the various couples and their secretions is also deserving of study. Of these, precipitation, agglutination, complementfixation, and immuno-electrophoretic reactions are all available for study. It was decided to explore precipitation first. Several methods were tried, from simple diffusion techniques to bi-dimensional methods of the Ouchterlony type. Each had disadvantages of one sort or another, chiefly related to either their relative insensitivity or lack of specificity, or to the small volume of material available for testing, since a man with NSU often has very little discharge. The method finally adopted as suit-

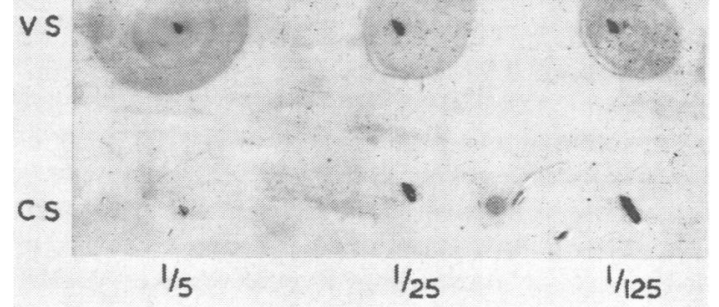

FIG. 2.-Results of placing drops of female consort's vaginal and cervical secretions in dilutions of $1: 5,1: 25$, and $1: 125$, on cellulose acetate paper impregnated with the patient's serum.

able for adaptation to the situation being investigated and to the restrictions imposed by its nature, was the cellulose acetate bi-dimensional immunodiffusion technique of Kohn (1964).

This consists of immersing strips of cellulose acetate paper in a preparation containing the antibody; placing drops of various dilutions of the suspected antigen on to it; allowing it to dry; leaving it under oil for 24-48 hours; removing the oil in Teepol solution; washing off the Teepol under a tap; and then staining the paper with 0.001 per cent. to 0.002 per cent. Nigrosin in acetic acid. This is a very sensitive stain and will detect even small amounts of protein. Using this method, urethral discharge and serum from the male patient have been exposed to each other, to the buffer alone, and to the vaginal and cervical secretions of the female consort.

Marked reactions between urethral discharge and serum of male patients and vaginal secretion of their female consorts at dilutions up to $1: 125$ have been obtained in some cases, but not consistently. No response has been observed so far as cervical secretions are concerned (Figs 1 and 2), neither has there been any reaction between the patient's own 
serum and his urethral discharge, such as would be expected if this were an auto-immune situation.

Further investigation of these precipitation reactions is continuing.

Skin tests also have an important place in the investigation of the nature of possibly allergic conditions. The skin reactions obtained from the intradermal injections of a saline solution of vaginal secretion and cervical secretions of the patient's consort have been compared with those obtained by the injection of similar secretions both from non-related females and from saline alone. Comparison has also been made with the reactions of a control male, by means of the injection of vaginal and cervical secretions from the patient's consort. Apart from the saline control some response has been obtained in all cases from the small series carried out, probably owing to the presence of foreign protein, but the reaction was quickest in onset, more extensive, and more prolonged between the patient and the consort's vaginal secretion. It is of interest in this connexion that Grimble and Csonka (1955), skintesting patients with a variety of venereal diseases with antigen prepared from the urethral secretions of patients with NGU, obtained positive reactions in hardly any of those who themselves had NGU, compared with only 3 per cent. of those with gonorrhoea.

The ultimate test of the allergic hypothesis is, of course, that of provocation. Thus the instillation of sterilized vaginal secretion into the urethra of the supposedly sensitized and susceptible male should provoke a recurrence of the clinical condition, against an absence of this response in control cases.

This has so far been possible on a single occasion only. In this instance a reliable attender, believed to be monogamous, but with a history of four recurrences of NGU over the past twelve months, each attack being satisfactorily cured, and his consort attending for investigation and "insurance" treatment on each occasion, had approximately $1 \mathrm{ml}$. of a saline suspension of the consort's vaginal secretion instilled into his urethra. He was instructed not to pass urine for as long as possible and this proved to be six hours. He developed urethral discharge on the third day.

It is not contended that the evidence so far adduced is proof of the allergic basis of the hitherto unexplained nature of many, if not most, cases of NSU; but it would seem sufficient to increase substantially the degree of possibility and to warrant the continuation and development of the investigation of the hypothesis.

\section{Summary}

Previous work on the nature of non-specific urethritis (NSU) is reviewed and the theoretical possibility of it being an allergic disease discussed.

A study and analysis of the case records of a series of 100 patients is described. The particular points established are that NSU tends both to arise and to recur in stable rather than casual relationships, and is characterized by a high degree of consort specificity; by a tendency for the first attack to occur after more than one exposure with a particular consort, but within the first few months of their association; by frequency of recurrence, especially following exposure with the same consort, whether treated or not. It is submitted that these factors are suggestive of the presence of an allergic rather than an infective process. Methods of investigating the hypothesis further are reviewed and preliminary results reported.

This study would hardly have been possible without the encouragement, advice, and practical assistance of Dr C. S. Nicol, physician in charge of the Venereal Diseases Departments at St Bartholomew's Hospital and St Thomas's Hospital; Dr Mark Ridley, clinical pathologist, St Thomas's Hospital; and Dr J. Kohn, consultant pathologist, Queen Mary's Hospital, Roehampton. I am also indebted to the nurses and technicians in the Lydia Department, St Thomas's Hospital, for their help in collecting the necessary specimens, and to Miss R. Grau for assistance with the preparation of this paper for publication.

\section{REFERENCES}

Ambrose, S. S., and Taylor, W. W. (1953). Amer.J. Syph., 37,501 .

Amies, C. R., and Jones, S. A. (1957). Canad. J. Microbiol., 3, 579 .

Auckland, G., and Preston, W. J. (1954). Brit. J. vener. Dis., 30, 81.

Babione, R. W., and Graham, R. S. (1952). Amer. J. Syph., 36, 480.

Baier, G. F., (1949). Bull. U.S. Army med. Dep., 9, 679.

Bedson, S. P. (1950). Brit. J. vener. Dis., 26, 177.

Beveridge, W. I. B., Campbell, A. D., and Lind, P. E. (1946). Med. J. Aust., 1, 179.

Boyd, J. T., Csonka, G. W., and Oates, J. K. (1958). Brit. J. vener. Dis., 34, 40 .

Card, D. H. (1959). Ibid., 35, 27.

Coutts, W. E. (1948). Ibid., 24, 109.

Crouch, R. D., Reese, J. E., and Boudreau, H. J. (1953). U.S. armed Forces med. J., 4, 1159.

Csonka, G. W., and Furness, G. (1960). Brit. J. vener. Dis., 36, 181.

Dienes, L., and Smith, W. E. (1942). Proc. Soc. exp. Biol. (N.Y.), 50, 99.

Doyle, J. O., Gill, A. J., and Laird, S. M. (1957). Brit. J. vener. Dis., 33, 100.

Dunlop, E. M. C., Jones, B. R., and Khalaf Al-Hussaini, M. (1964). Ibid.,' 40, 33. 
Durel, P., Roiron-Ratner, V., Siboulet, A., and Sorel, C. (1954). Brit. J. vener. Dis., 30, 69.

Edmunds, P. N. (1959). J. Obstet. Gynaec. Brit. Emp., 66, 917.

Feo, L. G., Varano, N. R., and Fetter, I. R. (1956). Brit. J. vener. Dis., 32, 233.

Ford, D. K. (1956). Ibid., 32, 184. (1958). Ibid., 34, 53.

- and Duvernet, M. (1963). Ibid., 39, 18.

Forgan, R. (1964). Personal communication.

Fowler, W. (1958). Brit. J. vener. Dis., 34, 166.

Freundt, E. A. (1956). Ibid., 32, 188.

Gardner, H. L., and Dukes, C. D. (1954). Science, 120, 853.

- - (1955). Amer. J. Obstet. Gynec., 69, 962. (1959). Ann. N.Y. Acad. Sci., 83, 280.

Gartman, E., and Leibovitz, A. (1955). Brit.J. vener. Dis., 31, 92.

Grimble, A. (1963). Ibid., 39, 246.

and Csonka, G. W. (1955). Ibid., 31, 228.

Haight, T. H. (1956). "Antibiotics Annual, 1955-1956", p. 648. Medical Encyclopedia, New York.

Halberstaedter, L., and von Prowazek, S. (1910). Berl. klin. Wschr., 47, 661 .

Harkness, A. H. (1945). Brit. J. vener. Dis., $21,93$.

(1950). "Non-gonococcal Urethritis". Livingstone. Edinburgh.

(1953). Brit. J. vener. Dis., 29, 134.

- and Henderson-Begg, A. (1948). Ibid., 24, 50.

Heltai, A. (1959). Ann. N.Y. Acad. Sci., 83, 290.

Hirakida, M. (1958). Med. J. mutual Aid Ass., 7, 10.

Johnston, G. A. W., and McEwin, J. (1945). Med.J. Aust. . $1,368$.

Jones, B. R. (1964). Brit. J. vener. Dis., 40, 3.

-, Khalaf Al-Hussaini, M., and Dunlop, E. M. C. (1964). Ibid., 40, 19.

Kershaw, P. S., and Lindsay, J. G. (1956). J. roy. Army med. Cps, 102, 56.

Khalaf Al-Hussaini, M., Jones, B. R., and Dunlop, E. M. C. (1964). Brit. J. vener. Dis., 40, 25.

Kleineberger-Nobel, E. (1959). Brit. med. J., 1, 19.

Kohn, J. (1964). Personal communication.

Laidig, C. E., and Berg, P. (1957). J. Urol. (Baltimore), 77, 457.

Lanceley, F. (1953). Brit. J. vener. Dis., 29, 213.

Lapage, S. P. (1961). Acta path. microbiol. scand., 52, 34.

Leach, W. (1959). Brit. J. vener. Dis., 35, 223.

Leopold, S. (1953). U.S. armed Forces med. J., 4, 263.

Levy, B. (1964). Personal communication.

Lindner, K. (1910). Wien. klin. Wschr., 23, 283.

Longhin, S., Teodosiu, T., and Vintici, V. (1959). Derm.vener. (Buc.), 4, 385.

Lyall, T. (1953). Brit. J. vener. Dis., 29, 151.

Macfarlane, W. V., and Johns, H. M. (1958). Ibid., 34, 101.

Morrison, A. I. (1963). Ibid., 39, 118.

Morton, R. S., and Morrison, A. I. (1963). Ibid., 39, 244.

and Read, L. (1957). Ibid., 33, 223.

Moustardier, G., Brisou, J., and Perrey, M. (1954). Ann. Derm. Syph. (Paris), 81, 521.

Nardelli, L. (1960). Minerva derm., 35, 451.

(1961). Arch. klin. exp. Derm., 213, 817.

Nicol, C. S., and Edward, D. G. ff. (1953). Brit. J. vener. Dis., 29, 141.

Pearson, C. M., Waksman, B. H., and Sharp, J. T. (1961). J. exp. Med., 113, 485 .

Röckl, H., and Nasemann, T. (1959). Urol. Int. (Basel), 9, 266.

- , -

Salaman, M. H. (1946). Brit. J. vener. Dis., 22, 47.
Schulte, T. L., Reynolds, L. R., and Hammer, H. J. (1954). Calif. Med., 80, 380.

Sebastiani, F. (1960). Arch. ital. Derm., 30, 78.

Shepard, M. C. (1954). Amer. J. Syph., 38, 113. (1956). J. Bact., 71, 362

Siboulet, A. (1955). J. Urol. méd. chir., 61, 74.

- (1960). Concours méd. (Paris), 82, 3501.

- and Galistin, P. (1962). Brit. J. vener. Dis., 38, 209.

Siebert, W. (1910). Münch. med. Wschr., 57, 1279.

Steinberg, J. (1938). Calif. west. Med., 49, 291.

Thygeson, P., and Mengert, W. F. (1936). Arch. Ophthal. (Chicago), 15, 377. and Stone, W. J. (1942). Ibid., 27, 91.

Wagner, B. M., Morse, W. H., and Kuhns, D. M. (1953). Amer. J. publ. Hlth, 43, 853.

Weston, T. E. T., and Nicol, C. S. (1963). Brit. J. vener. Dis., 39, 281.

Whitney, C. M. (1931). New Engl. J. Med., 205, 20.

Whittington, M. J. (1962). Brit. J. vener. Dis., 38, 200.

Wilkinson, A. E., and Whittington, M. J. (1959). Quoted by King, A. (1964) in "Recent Advances in Venereology", ch. 13. Churchill, London.

Willcox, R. R. (1953). Brit. J. vener. Dis., 29, 225. (1954). Brit. med. J., 1, 13.

(1955a). J. chron. Dis., 1, 381.

(1955b). Brit. J. vener. Dis., 31, 89.

(1958). Brit. J. clin. Pract., 12, 479.

(1959). Brit. J. vener. Dis., 35, 264.

(1959). Ibid., 35, 264.

Howard, E. M., and Findlay, G. M. (1954). Ibid., 30, 31.

Williams, S. (1946). Med. J. Aust., 1, 693.

Zinnemann, K., and Turner, G. C. (1963). J. Path. Bact., $85,213$.

\section{SUPPLEMENTARY BIBLIOGRAPHY}

Cuilleret, P., and Pellerat, J. (1951). Bull. Soc. franç. Derm. Syph., 58, 125.

Durel, P., and Borel, L. J. (1951). Ibid., 58, 144.

and Siboulet, A. (1959). "Traitement des suppurations urétro-génitales" [Bibliothèque de thérapeutique médicale]. Doin, Paris.

Gell, P. G. H., and Coombs, R. R. A. (1963). "Clinical Aspects of Immunology”. Blackwell, Oxford.

Humphrey, J. H., and White, R. G. (1963). "Immunology for Students of Medicine". Blackwell, Oxford.

Kleineberger-Nobel, E. (1959). Brit. J. vener. Dis., 35, 20.

Michail, C. P., and Papaevangelou, G. J. (1959). Acta microbiol. hellen., 4, 177.

Nardelli, L. (1957). Minerva derm., 32, 208.

Pastinszky, I. (1959). Urol. int . (Basel), 9, 288.

Patnaik, R. M. (1960). Antiseptic, 57, 139.

Siboulet, A. (1959). Urol. int. (Basel), 9, 146.

Tulasne, R., and Minck, R. (1959). "Les urétrites nongonococciques'. Manay, Paris.

Wilde, H. (1961). Arch. klin. exp. Derm., 213, 825.

\section{Origine allergique de l'urètrite non gonococcique}

\section{RÉSUMÉ}

On passe en revue les travaux faits sur la nature de l'urètrite non gonococcique et on discute la possibilité théorique de son origine allergique.

L'étude et l'analyse des observations d'une série de 100 malades met en évidence les faits caractéristiques suivants: l'urètrite non gonococcique (UNG) tend à se 
produire et à se répéter en cas de relations stables plutôt qu'en cas de relations passagères et est individualisée par un degré élevé de spécificité; généralement la première attaque tend à se produire après plus d'un contact avec un conjoint particulier, mais pas plus tard que pendant les premiers mois de l'association; les rechutes sont fréquentes, spécialement après contact avec le même conjoint, traité ou non.

Ces facteurs évoquent l'intervention d'un processus allergique plutôt qu'infectieux. On passe en revue les méthodes d'étude de cette hypothèse et on présente les premiers résultats. 